\title{
Potential use of new Colombian sources of betalains. Colorimetric study of red prickly pear (Opuntia dillenii) extracts under different technological conditions
}

\author{
María Jesús Cejudo-Bastante ${ }^{\mathrm{a}}$, Nelson Hurtado ${ }^{\mathrm{b}}$, Francisco J. Heredia ${ }^{\mathrm{a}, *}$ \\ a Food Color and Quality Lab., Dept. Nutrition and Food Science, Facultad de Farmacia, Universidad de Sevilla, 41012 Sevilla, Spain \\ b Departamento de Química, Universidad de Nariño, A.A. 1175 Pasto, Colombia
}

Keywords:

Opuntia dillenii

Differential tristimulus colorimetry

Betalains

Stability

\begin{abstract}
A B S T R A C T
A new source of betalains to be used as natural colorant (Opuntia dillenii) has been studied. The stability of O. dillenii extracts in different pHs and temperatures over time has been scrutinized. Our attention was focused on differential tristimulus colorimetry and betalain content related to the color, not previously conducted in conjunction in that raw material. On the basis of the results, cold storage conditions $\left(4^{\circ} \mathrm{C}\right)$ were optimal to maintain as possible the initial red color $\left(h_{a b}\right)$, lightness $\left(L^{*}\right)$ and betalain content of the 0 . dillenii extracts, regardless of $\mathrm{pH}$. Highly-acidic extracts $(\mathrm{pH} 4)$ manifested a significantly $(p<0.05)$ lower colorant intensity $\left(C^{*}{ }_{a b}\right)$ and betalain concentration (around 25\% and 35\%, respectively), with a clearer tendency toward yellowish tonalities (values of $h_{a b}$ from $45^{\circ}$ to $\left.90^{\circ}\right)$ over time. Furthermore, visually perceptible color changes $\left(\Delta E_{a b}^{*}>3\right)$ were induced among very acid ( $\mathrm{pH} 4$ ) and low-acidic ( $\mathrm{pH} 5$ and 6) extracts at each temperature.
\end{abstract}

\section{Introduction}

Opuntia is a shrub from America and brought to Spain in the nineteenth century, point at which it became widespread to other Mediterranean zones, and even to Asiatic countries. It usually grows in semi-desert climate, with an optimal low pluviometry for its growth (150-200 mm median annual precipitation). This cactus is characterized by yellow flowers, red fruits and thick, flat and stiff stems. The genus Opuntia belongs to the family of Cactaceae, with the species Opuntia-ficus indica being the most widespread, consumed and investigated. However, there are several other species of Opuntia, among which stand out 0 . dillenii (Ker-Gawl) Haw.

Prickly pears of 0 . dillenii have a very intense red color and acidic taste, with a great number of seeds (Medina, Rodríguez, \& Romero, 2007), and an average length and width around 4.0 and $3.2 \mathrm{~cm}$, respectively (Touil, Chemkhi, \& Zagrouba, 2010). Some studies about O. dillenii from different countries (Tunisia, Spain and Canada) have been reported on the basis of a general characterization: analysis of acidity, nitrogen or sugars (Touil et al., 2010), moisture, ${ }^{\circ}$ Brix, total fiber, protein, fat, ash, $\mathrm{pH}$, acidity, ascorbic acid, total phenolics and several minerals (Medina et al., 2007), and polysaccharides (Yang, Chen, Zhou, \& Zhang, 2013). In addition, the analysis of antioxidant activity has been a widely studied parameter in this kind of cactus, both in the entire fruit or separately in pulp, peel and seeds (Chang, Hsieh, \& Yen, 2008; Liu et al., 2009; Yang et al., 2013). These authors affirmed that 0 . dillenii had high values of antioxidant activity, above all seeds and peel. From a healthy point of view, Chang et al. (2008) established a relationship between the antioxidant activity of different parts of 0 . dillenii and the protective effect against low-density lipoprotein peroxidation. Also, in fact, this cactus has been commonly used as medicine to avoid inflammation, gonorrhea and ophthalmia, among others diseases (Touil et al., 2010).

The market is continuously changing and consumers are becoming more conscious about how the food and its ingredients could positively influence their health. In that way, the consumption of products with antioxidant and beneficial properties has recently increased. From an agro-alimentary point of view, the natural colorants are replacing the traditionally-consumed synthetic colorants for this purpose. As a consequence, new raw materials that could satisfy this target market have been found in flowers, fruits and vegetables. Among them, there are several species with a wide range of colors, which are due to the presence of different chemical families such as anthocyanins, chlorophylls and carotenoids. However, there is a group of colored compounds that was still poorly investigated, the so-called betalains.

Betalains are water-soluble compounds whose basic structure consists of a moiety of betalamic acid. Depending on the residue added, betalains are classified as: (i) red/purple betacyanins and (ii) yellow betaxanthins, when hydroxycinnamic acid derivatives or sugars, and amines or amino acids residues, respectively, are linked to betalamic 
acid (Herbach, Stintzing, \& Carle, 2006). Betalains are presented in a restricted number of families of the plant order Caryophyllales and of the genus Amanita of the Basidiomycetes (Waterman, 2007) and they have been studied in a large series of plants, vegetables and flowers (Azeredo, 2009; Kugler, Stintzing, \& Carle, 2007; Nemzer et al., 2011; Pavokovi \& Krsnik-Rasol, 2011). Among fruits, cactus pears have been widely studied (Castellanos-Santiago \& Yahia, 2008; Stintzing, Schieber \& Carle, 2002a, 2002b), taking O. ficus-indica the lead over the other kind of Opuntia. However, to the best of our knowledge, very scarce studies on betalains about other species of Opuntia, such as 0 . dillenii, have been reported.

Furthermore, despite such broad agro-alimentary implications as natural colorant, none of the research studies about colorimetry of 0 . dillenii has been found in bibliography either. In that way, the study was performed on 0 . dillenii, which wildly grows in the arid zone of Nariño, Colombia, and our interest was focused on the color characterization and betalain content. Moreover, not only a color characterization of $O$. dillenii is needed, but even the knowledge of its colorimetric behavior when it acts as colorant of other foodstuffs. Therefore, in order to establish the best commercial conditions of the natural colorant addition to other agro-alimentary foods, stability assays in different pHs and temperatures over time have been also carried out, which have not been previously attempted in that raw material.

\section{Materials and methods}

In order to reflect as possible with the technological conditions that O. dillenii may be involved when it is used as natural colorant, a monitoring of stabilization in different circumstances has been carried out. A colorimetry study and betalain content of 0 . dillenii extracts at three temperatures $\left(4^{\circ} \mathrm{C}, 20^{\circ} \mathrm{C}\right.$ and $\left.80^{\circ} \mathrm{C}\right)$ and $\mathrm{pHs}(4,5$ and 6$)$ has been conducted over time ( 0 and $5 \mathrm{~h}$, and 1, 2, 6, 8 and 12 days). The temperature of $80{ }^{\circ} \mathrm{C}$ has been applied only for one day in order to reproduce as possible real conditions. Those terms have been chosen in order to cover a wide range of foods (from vegetables to meat, for example) and diverse ways of food processing (refrigeration, room temperature or cooking).

\subsection{Chemical and solvents}

Sodium ascorbate was purchased from Panreac (Barcelona, Spain) and methanol of analytical grade from J. T. Baker (Baker, Mallinckrodt, Mexico). Hydrochloric acid and sodium hydroxide (J. T. Baker, Baker Mallinckrodt, Mexico) were used for adjusting $\mathrm{pH}$.

\subsection{Samples}

Red prickly pear samples ( 0 . dillenii) were collected in the village of Remolinos (Nariño, Colombia). A representative set of samples of up to a weight of about $2 \mathrm{~kg}$ was harvested, collecting mature fruits according to visual characteristics and similar size using a simple random sampling model of ten plants. After homogenization, only $1450 \mathrm{~kg}$ of fruits was taken into account, with an average weight of each fruit around $11 \mathrm{~g}$. They were carefully washed and dried, and prickles were manually removed. Fruits were cut into small pieces $\left(1 \mathrm{~cm}^{2}\right)$ and extracted with $1 \mathrm{~L}$ of methanol:water $(60: 40)$ for $24 \mathrm{~h}$ at $10{ }^{\circ} \mathrm{C}$ (maceration). After filtration, the organic solvent was evaporated at $35^{\circ} \mathrm{C}$ using a rotary evaporator (Heidolph, Schwabach, Germany) and the re-dissolved with distilled water (relation $1 \mathrm{~g} / \mathrm{mL}$ ) was lyophilized (Labconco, MO, USA). Lyophilized samples were stored at $4{ }^{\circ} \mathrm{C}$ until their analysis.

\subsection{Extract reconstitution}

$9.5 \mathrm{~mL}$ of methanol and water (50:50), containing $50 \mathrm{mM}$ of sodium ascorbate, were added to $3 \mathrm{~g}$ of lyophilized extract. Solutions were then stirred at $225 \mathrm{rpm}$ for $10 \mathrm{~min}$ in darkness, in order to avoid possible degradation by light. Afterwards, a centrifugation at $12,000 \times g$ at $10{ }^{\circ} \mathrm{C}$ and 5 min was carried out, according to the method proposed by (Cejudo-Bastante, Hurtado, Mosquera, \& Heredia, 2014). Supernatants were separated and, in order to achieve the complete dissolution of the lyophilized extract, the procedure was developed once more with the extraction solution and finally with $100 \%$ methanol. Later, the extract obtained was concentrated in vacuum $\left(30^{\circ} \mathrm{C}\right)$ and resuspended until $15 \mathrm{~mL}$ with purified water. All experiences were carried out in triplicate.

\subsection{Colorimetric measurements}

A Hewlett-Packard UV-vis HP8452 spectrophotometer (Palo Alto, CA) was employed to develop color measurements. The whole visible spectrum (380-770 nm) was recorded at constant intervals $(\Delta \lambda=2 \mathrm{~nm}$ ) using $2 \mathrm{~mm}$ path length glass cells and distilled water as reference. The original software CromaLab@ was used for determining the CIELAB parameters (Heredia, Álvarez, González-Miret, \& Ramírez, 2004), following the Commission Internationale de L'Eclairage's recommendations (CIE, 2004): the CIE $196410^{\circ}$ Standard Observer and the Standard Illuminant D65. Euclidean distance between two points in the three-dimensional space define by $L^{*}, a^{*}$, and $b^{*}$ were used for calculating color differences $\left(\Delta E_{a b}^{*}\right): \Delta E_{a b}^{*}=\left[\left(\Delta L^{*}\right)^{2}+\left(\Delta a^{*}\right)^{2}+\left(\Delta b^{*}\right)^{2}\right]^{1 / 2}$.

\subsection{Spectrophotometric quantification of betalains}

The UV-vis spectra were recorded from $360-800 \mathrm{~nm}$ in order to develop a photometric quantification of betalains, according to the method proposed by (Svenson, Smallfield, Joyce, Sansom, \& Perry, 2008). Maximum absorbance of 484 and $535 \mathrm{~nm}$ was reported to quantify betaxanthins and betacyanins, respectively. Betalain content (B) was developed by the following equation:

$[\mathrm{B}](\mu \mathrm{g} / \mathrm{g})=[1000(\mathrm{Abs})(\mathrm{D})(\mathrm{V})(\mathrm{MW}) /(\varepsilon)(\mathrm{L})(\mathrm{W})]$

where Abs is the value of maximum absorbance at 484 or $535 \mathrm{~nm}$, D is the dilution factor, $\mathrm{V}$ is the final volume $(\mathrm{mL})$ of the extracts, MW and $\varepsilon$ are the molecular weight and the molar extinction coefficient of betanin $\left(550 \mathrm{~g} / \mathrm{mol}\right.$ and $60,000 \mathrm{~L} /(\mathrm{mol} \mathrm{cm})$ in $\left.\mathrm{H}_{2} \mathrm{O}\right)$ and indicaxanthin ( $308 \mathrm{~g} / \mathrm{mol}$ and $48,000 \mathrm{~L} /(\mathrm{mol} \mathrm{cm})$ in $\mathrm{H}_{2} \mathrm{O}$ ), the major betacyanin and betaxanthin presented in Opuntia sp., respectively, $\mathrm{L}$ is the path-length $(0.2 \mathrm{~cm})$ and $\mathrm{W}$ the dried weight of the sample $(\mathrm{g})$. All measurements were carried out in triplicate.

\subsection{Statistical analysis}

Statistical analysis was carried out by using Statistica version 8.0 software (Statistica, 2007). Univariate analyses of variance (Tukey test and ANOVA) were applied to discriminate among the means of chemical data.

\section{Results and discussion}

The effect of temperature and $\mathrm{pH}$ over time on the color and betalain stabilization has been investigated. Several temperatures $\left(4^{\circ} \mathrm{C}, 20^{\circ} \mathrm{C}\right.$ and $80^{\circ} \mathrm{C}$ ) and $\mathrm{pH}$ values ( $\mathrm{pH} \mathrm{4,5}$ and 6 ) have been selected in order to cover a wide range of processing and storage conditions, and acidities of raw materials where 0 . dillenii was added as colorant. In order to observe the evolution during storage and/or cooking, the three perspectives (CIELAB color parameters, tristimulus differential colorimetry and betalain content) have been jointly studied over time ( 0 and $5 \mathrm{~h}$, and 1, 2, 6, 8 and 12 days). In order to have a better understanding, the effect of temperature and $\mathrm{pH}$ has been separately discussed. Relative standard deviations were always $<10 \%$. 


\subsection{Effect of temperature over time}

\subsubsection{Temperature and colorimetric characteristics}

Regardless of $\mathrm{pH}$, the major and significant $(p<0.05)$ differences on color caused by temperature were found in hue $\left(h_{a b}\right)$ (Fig. 1). When $O$. dillenii extracts underwent cold storage $\left(4{ }^{\circ} \mathrm{C}\right)$, the red color was maintained without significant differences $(p>0.05)$ at least for 2 days of treatment. When time passed, the variations of shade were significant $(p<0.05)$ but only of $15 \%$ among the beginning and after 12 days of storage. However, when extracts were kept at room temperature $\left(20^{\circ} \mathrm{C}\right)$ or after cooking $\left(80^{\circ} \mathrm{C}\right)$, a remarkable and significant $(p<0.05)$ increase of hue was noticed, highlighting a change of the typology of color from reddish to yellowish. That fact could be due to an accelerated hydrolysis phenomena catalyzed by temperature, since betanin (red) could produce betalamic acid (yellow-orange) and cyclo Dopa-5-0-glucoside (colorless) as intermediary products (SanchezGonzalez, Jaime-Fonseca, San Martin-Martinez, \& Zepeda, 2013). Significant differences $(p<0.05)$ were observed at each time-point after the two days of treatment among $4{ }^{\circ} \mathrm{C}$ and $20^{\circ} \mathrm{C}$, and with samples after only $5 \mathrm{~h}$ of cooking $\left(80^{\circ} \mathrm{C}\right.$ ) (Fig. 1). Therefore, regardless of the $\mathrm{pH}$ of the foodstuff to which the natural colorant $O$. dillenii would be incorporated, it is better to keep it under refrigeration in order to maintain as possible the initial red color.
Furthermore, an upward trend of the values of lightness over time was observed. From the sixth day of treatment, and regardless of $\mathrm{pH}$, the extracts stored at room temperature $\left(20^{\circ} \mathrm{C}\right)$ developed a remarkable increase of lightness, being significantly higher $(p<0.05)$ in comparison with those conserved at $4{ }^{\circ} \mathrm{C}$. Thus, cold conditions permitted a better conservation of the initial lightness of the extracts. It is remarkable that, for both hue $\left(h_{a b}\right)$ and lightness $\left(L^{*}\right)$, samples kept at $20^{\circ} \mathrm{C}$ for 12 days showed similarly values than those heated at $80^{\circ} \mathrm{C}$ in only $5 \mathrm{~h}$. That fact evidenced that the color degradation of 0 . dillenii was accelerated by the thermal treatment, as affirmed (El Hosry, Auezova, Sakr, \& Hajj-Moussa, 2009).

Moreover, temperature did not exerted a significant $(p>0.05)$ effect on chroma $\left(C^{*}{ }_{a b}\right)$ at each time-point neither in highly- nor low-acidic extracts, causing the same effect in terms of tinctorial strength to kept them at $20^{\circ} \mathrm{C}$ or $4{ }^{\circ} \mathrm{C}$. As expected, heating at $80^{\circ} \mathrm{C}$ provoked a remarkable and significative $(p<0.05)$ increase (around $50 \%$ ) of chroma values, turning towards a more saturated color.

The $\left(a^{*} b^{*}\right)$-color diagram exposes 0 . dillenii extracts at the different pHs and temperatures over time, and it has been represented in Fig. 2. All samples were situated in the first quadrant of the diagram, but very close to the second quadrant for the last points of the treatment. Regardless of $\mathrm{pH}$, the natural tendency of 0 . dillenii colorant was directed to the enhancement of $b^{*}$ and the diminution of $a^{*}$ levels, and
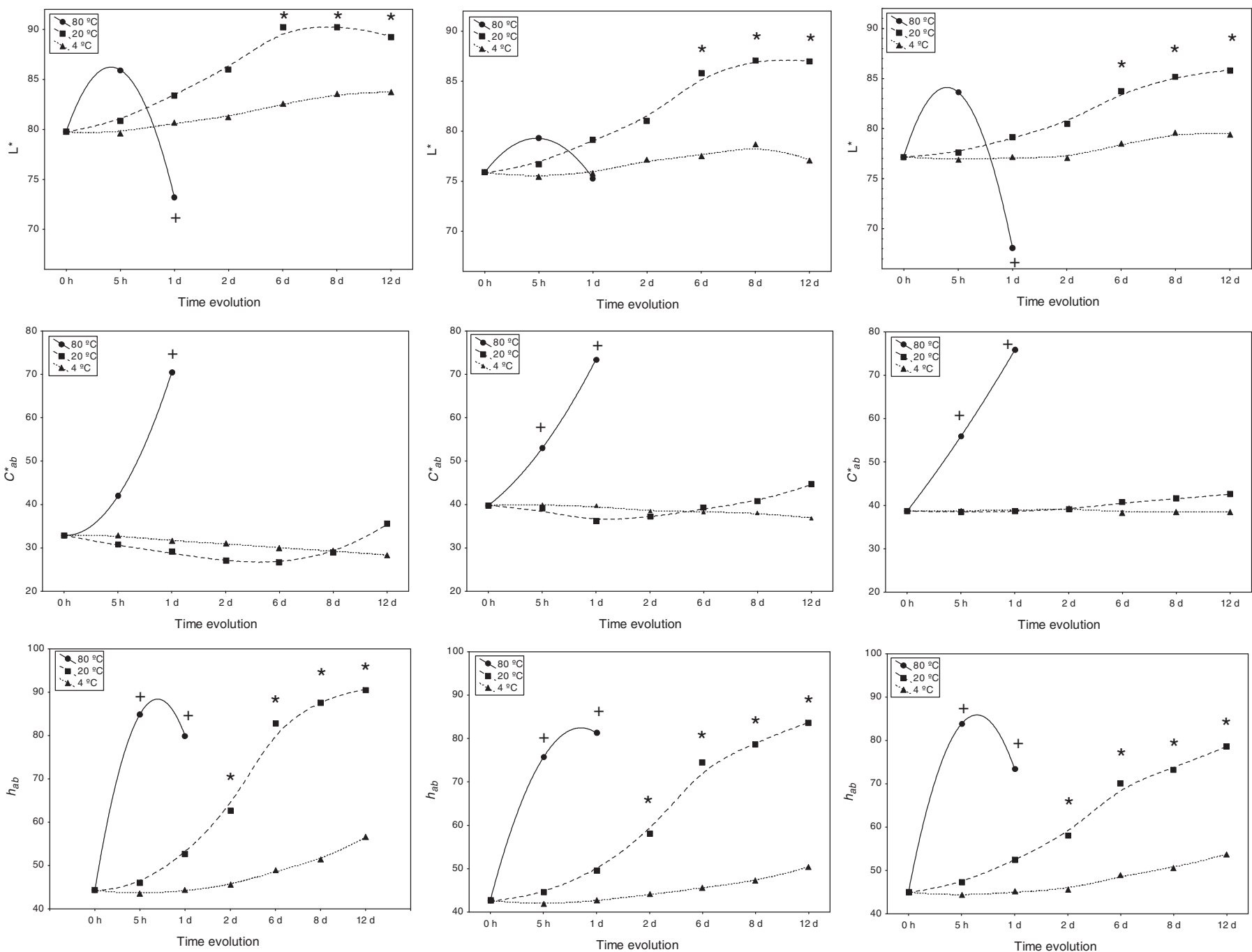

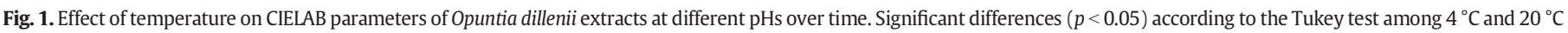
$\left({ }^{*}\right)$, and among $80^{\circ} \mathrm{C}$ and the rest of temperatures $(+)$. 
pH 4

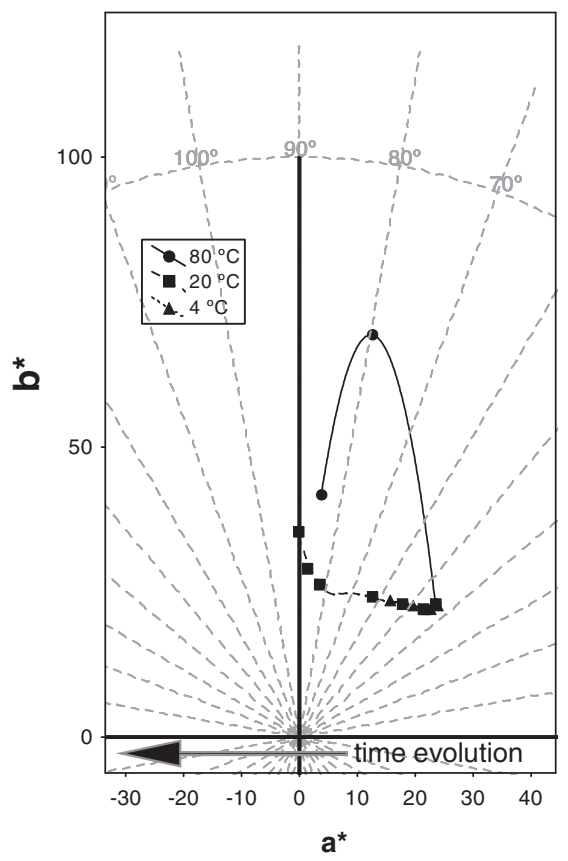

pH 5

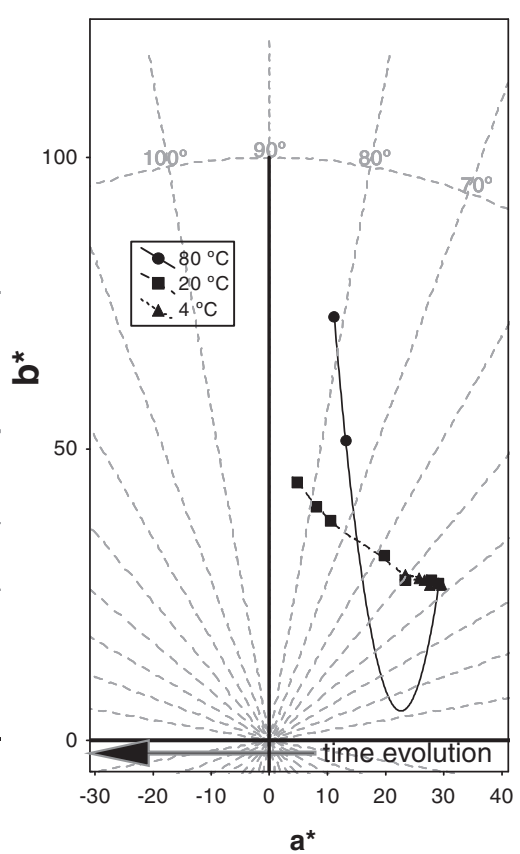

pH 6

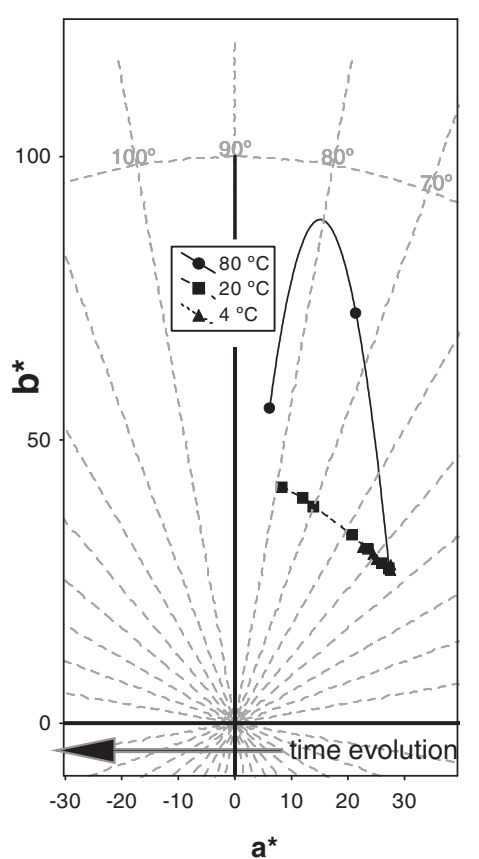

Fig. 2. Effect of temperature on CIELAB color space $\left(a^{*} b^{*}\right)$-plane of Opuntia dillenii extracts at different pHs over time.

it was more noticeable as temperature increased. Indeed, samples kept under refrigeration exhibited a scarce percentage of variation from the beginning to the end of the treatment, assuming similar values of $b^{*}$ and $a^{*}$ the samples under cold storage for 12 days and those conserved at room temperature for only 2 days. When extracts were cooked $\left(80{ }^{\circ} \mathrm{C}\right)$, only $5 \mathrm{~h}$ is enough to situate samples in a similar location than after 12 days at $20^{\circ} \mathrm{C}$ (Cai, Sun, \& Corke, 1998). Therefore, the temperature supposed a catalyst of the color degradation of the Opuntia natural colorant towards more yellowish dyes. The color loss could probably due to dehydrogenation and decarboxylation reactions, resulting in the neobetanin (yellow) and 17-decarboxy-betanin (orange-red) compounds (Herbach, Stintzing, \& Carle, 2004).

In conclusion, temperature exerted an important influence on the color of the 0 . dillenii extracts. For being used as natural colorant, and regardless of the $\mathrm{pH}$ of the foodstuff, it is better to keep them under refrigeration in order to maintain as possible the initial values of hue $\left(h_{a b}\right)$ and lightness $\left(L^{*}\right)$. So, 0 . dillenii extracts could be added to both highly-acidic (such as vegetables, salads, jams) as low-acid foods (meats, etc.) to improve their red color, provided that they were kept under cold conditions.

\subsubsection{Temperature and differential colorimetry}

With the aim of inquiring into the effect of temperature on color differences $\left(\Delta E_{a b}^{*}\right)$, only samples submitted to cold refrigeration and room temperature $\left(4{ }^{\circ} \mathrm{C}\right.$ and $20{ }^{\circ} \mathrm{C}$ ) have been taken into account (Fig. 3). Obvious color differences occurred when samples submitted to $80{ }^{\circ} \mathrm{C}$ were considered (data not shown), due to their colorimetric characteristics that greatly differed from those obtained by the rest of temperatures.

Taking into account that the perceptible colorimetric differences to the human eyes have been established around three CIELAB units (Fernández-López et al., 2013; Martínez, Melgosa, Pérez, Hita, \& Negueruela, 2001), a visually appreciable effect on $\Delta E^{*}{ }_{a b}$ took place when compared samples submitted to both temperatures at each $\mathrm{pH}$, concluding that $O$. dillenii extracts suffered from thermolability. Those color differences were much more marked over time, even reaching values of 20 units between the beginning and the end of the treatment. The percentage of the quadratic increases of lightness, chroma and color shade to know the role of each color attribute respect $\Delta^{2} E_{a b}^{*}$ was calculated (Gordillo et al., 2012). Hue and lightness $\left(\Delta^{2} H\right.$ and $\left.\Delta^{2} L\right)$ actively contributed to the color differences, given the evolution of the color shade (towards yellowish tonalities) when samples were stored at room temperature.

\subsubsection{Temperature and betalain content}

Fig. 4 shows the characteristic spectrum of 0 . dillenii extracts, with maximum wavelengths around 483 and $535 \mathrm{~nm}$, corresponding to the two groups of betalains studied (betaxanthins and betacyanins, respectively). By the measurement of the absorbance at those wavelengths, the content of betalains were also calculated (Fig. 5).

Over time, and considering each $\mathrm{pH}$, the instability increased as temperature raised because a diminution of the absorbance at both wavelengths occurred (Fig. 4). Regarding temperature, while the spectra of the two maximum wavelengths were perfectly marked under refrigeration (even after 12 days of treatment), they became fading to turn into a flat line after 6 days of storage at $20{ }^{\circ} \mathrm{C}$, and only $5 \mathrm{~h}$ at $80{ }^{\circ} \mathrm{C}$. As a matter of fact, the effect of temperature was also observed in the time-sequence evolution (black and dotted lines, Fig. 4). Therefore, it must be affirmed that temperature accelerated the process of

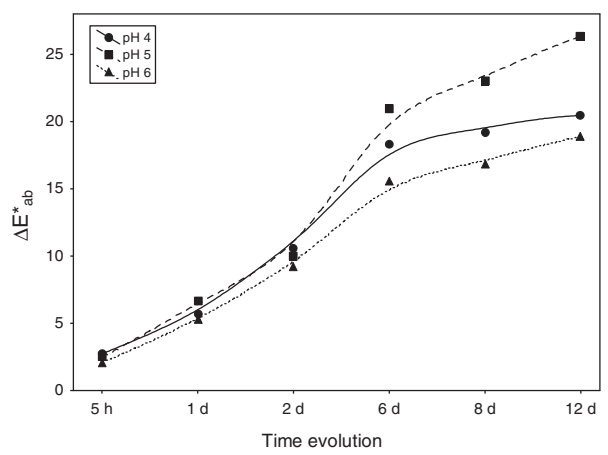

Fig. 3. Color variation $\left(\Delta \mathrm{E}_{\mathrm{ab}}^{*}\right)$ of Opuntia dillenii extracts between $20{ }^{\circ} \mathrm{C}$ and $4{ }^{\circ} \mathrm{C}$ at different pHs. 
pH 4

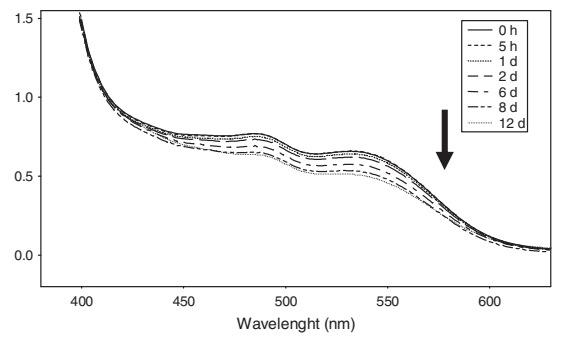

pH 5
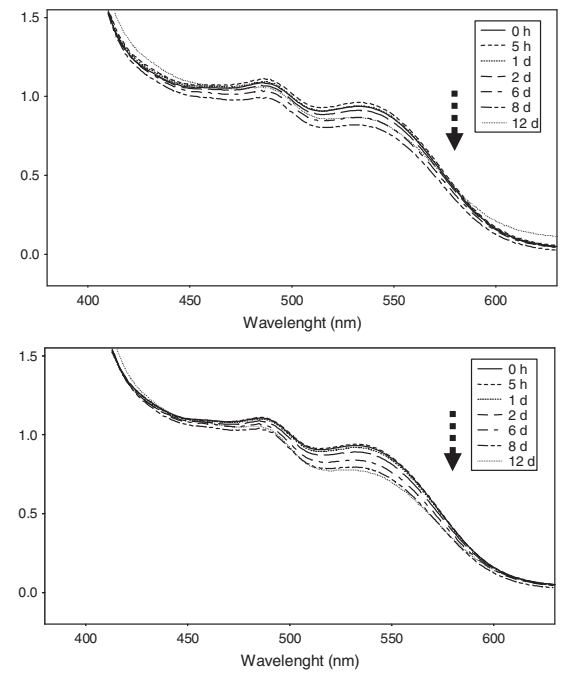
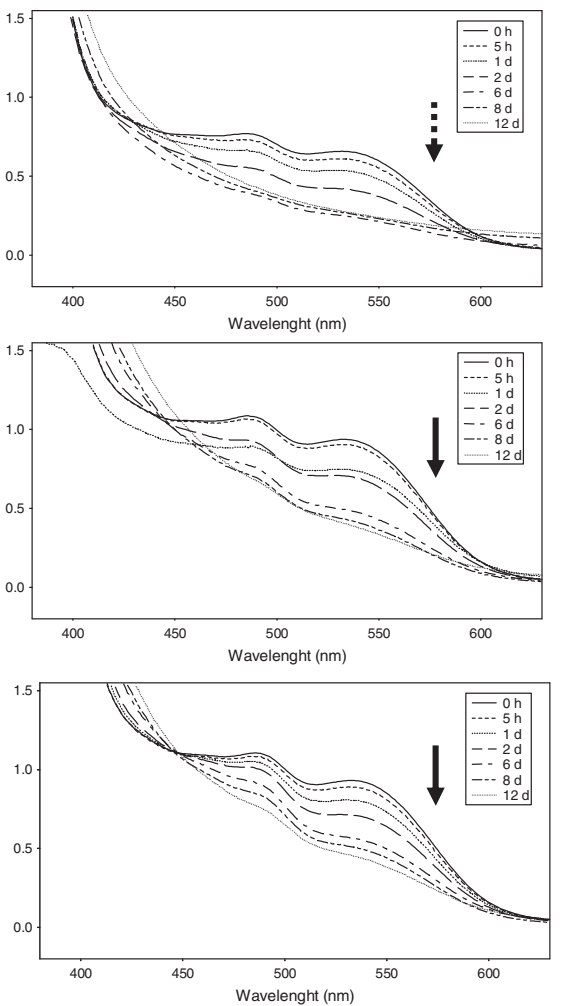
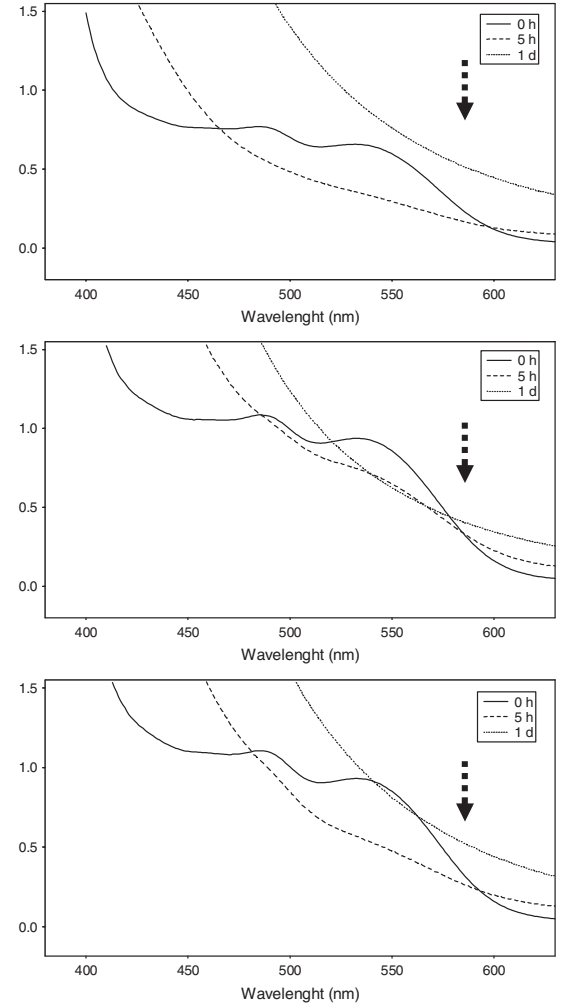

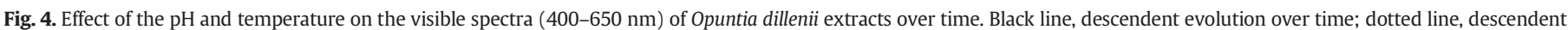
evolution over time except for the day 12 .

spectra degradation, being 0 . dillenii a thermo sensitive raw material under those conditions. When samples were cooked $\left(80^{\circ} \mathrm{C}\right)$, the logical downward trend of absorbance values was not followed over time, but the absorbance at $420 \mathrm{~nm}$ was remarkably enhanced (dotted line, Fig. 4). That fact revealed a possible oxidation and/or accelerated browning, in agreement with El Hosry et al. (2009) and Fernández-Zurbano
pH 4
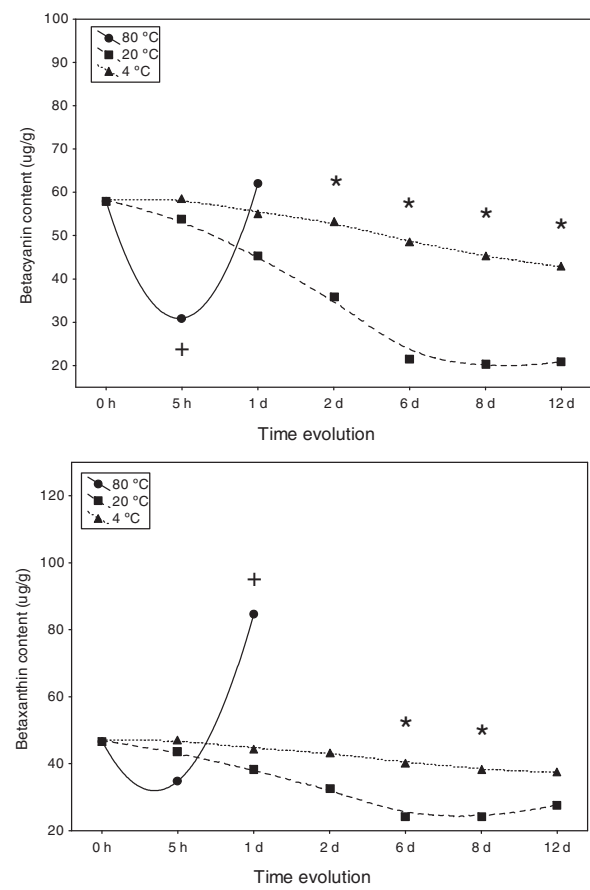

pH 5
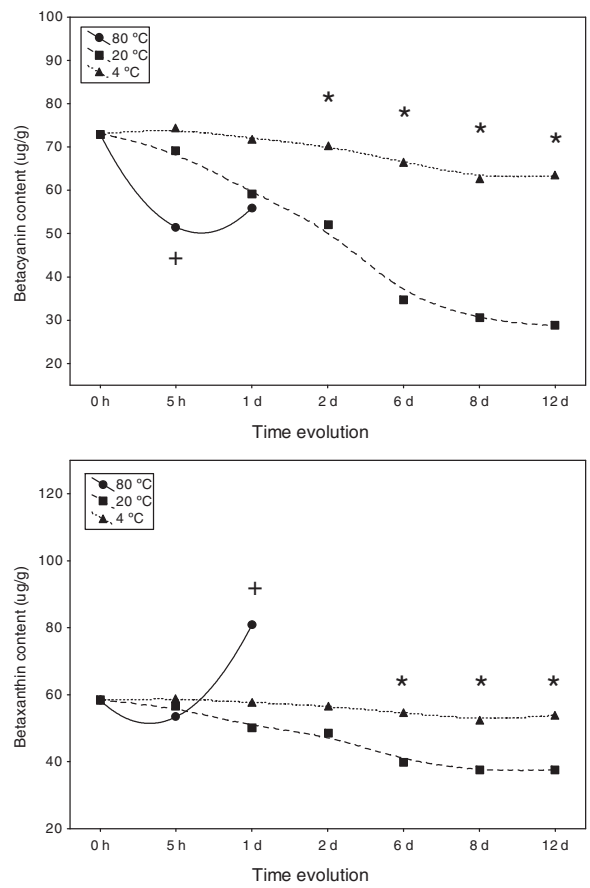

pH 6
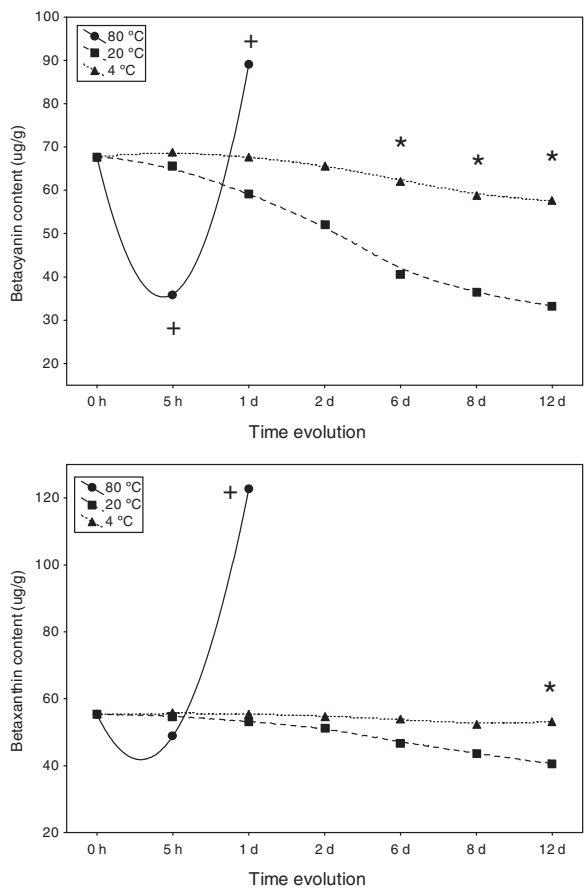

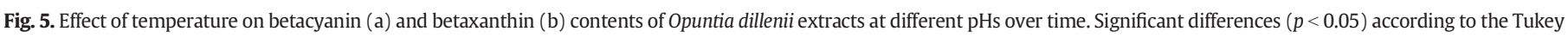
test among $4{ }^{\circ} \mathrm{C}$ and $20^{\circ} \mathrm{C}\left({ }^{*}\right)$, and among $80^{\circ} \mathrm{C}$ and the rest of temperatures $(+)$. 
et al. (1995) who demonstrated that an oxidation of wine phenolics is derived from a severe thermal treatment.

With regard to betalains, their content at the beginning of the treatment of both betacyanins and betaxanthins was similar at each $\mathrm{pH}$ (60-70 $\mu \mathrm{g} / \mathrm{g}$ and 50-60 $\mu \mathrm{g} / \mathrm{g}$, respectively). Similar values were also reported by Butera et al. (2002) in O. ficus-indica extracts, owing to the overlapping of betanin absorbance with the absorbance of indicaxanthin. In general, the amount of betalains of 0 . dillenii extracts decreased over time (Fig. 5), being the temperature an important factor on their pattern evolution. These results were in agreement with those obtained by Castellar et al. (2006) in other species of Opuntia sp.

The effect of temperature began to be significantly $(p<0.05)$ marked from the two days of treatment. Regardless $\mathrm{pH}$, if extracts were conserved in the absence of cold storage, remarkable losses of betacyanin content (around 40-65\%) were highlighted after the 12 days of treatment, versus the $11-25 \%$ observed at $4{ }^{\circ} \mathrm{C}$. In the case of betaxanthins, the losses were situated around $30 \%$. Moreover, the conservation under cold conditions $\left(4^{\circ} \mathrm{C}\right.$ ) made the extracts been maintained as possible the initial content of betalains (both betacyanins and betaxanthins), having significantly $(p<0.05)$ higher amounts in comparison with room storage conditions at each time-point (Fig. 5). When extracts were cooked $\left(80^{\circ} \mathrm{C}\right)$, it took only $5 \mathrm{~h}$ to reduce by $50 \%$ the concentration of betacyanins and betaxanthins. Similar results were found when three species of 0 . indica (red, yellow and white) were thermally submitted for one hour (Sanchez-Gonzalez et al., 2013). However, the fact that their content greatly and significantly $(p<0.05)$ increases after one day of treatment lead us to think that an accelerated browning occurred, in light of the great maximum absorption at $420 \mathrm{~nm}$.

\subsection{Effect of $\mathrm{pH}$ over time}

\subsection{1. $\mathrm{pH}$ and colorimetric characteristics}

The effect of $\mathrm{pH}$ on several perspectives (CIELAB color parameters, tristimulus differential colorimetry and betalain content) has been also scrutinized.

At the beginning of the process $(0 \mathrm{~h})$ there were significant $(p<0.05)$ differences among $\mathrm{pH}$ values, above all in lightness and chroma ( $L^{*}$ and $C^{*}{ }_{a b}$ ) (Fig. 6). Concretely, extracts adjusted to $\mathrm{pH} 4$ exhibited a significantly $(p<0.05)$ lower color intensity $\left(C_{a b}^{*}\right)$ and higher lightness $\left(L^{*}\right)$ than the rest of $\mathrm{pHs}$, being insignificant the differences on hue $\left(h_{a b}\right)$ (Fig. 6).

Over time, and regardless of the temperature applied, it is highlighted the significant $(p<0.05)$ differences on chroma $\left(C_{a b}^{*}\right)$ among samples. In that way, $O$. dillenii extracts at very acid $\mathrm{pH}$ displayed significantly $(p<0.05)$ the lowest values of chroma at each time-point. That fact means that it could be necessary to add more quantity of colorant to
$4{ }^{\circ} \mathrm{C}$
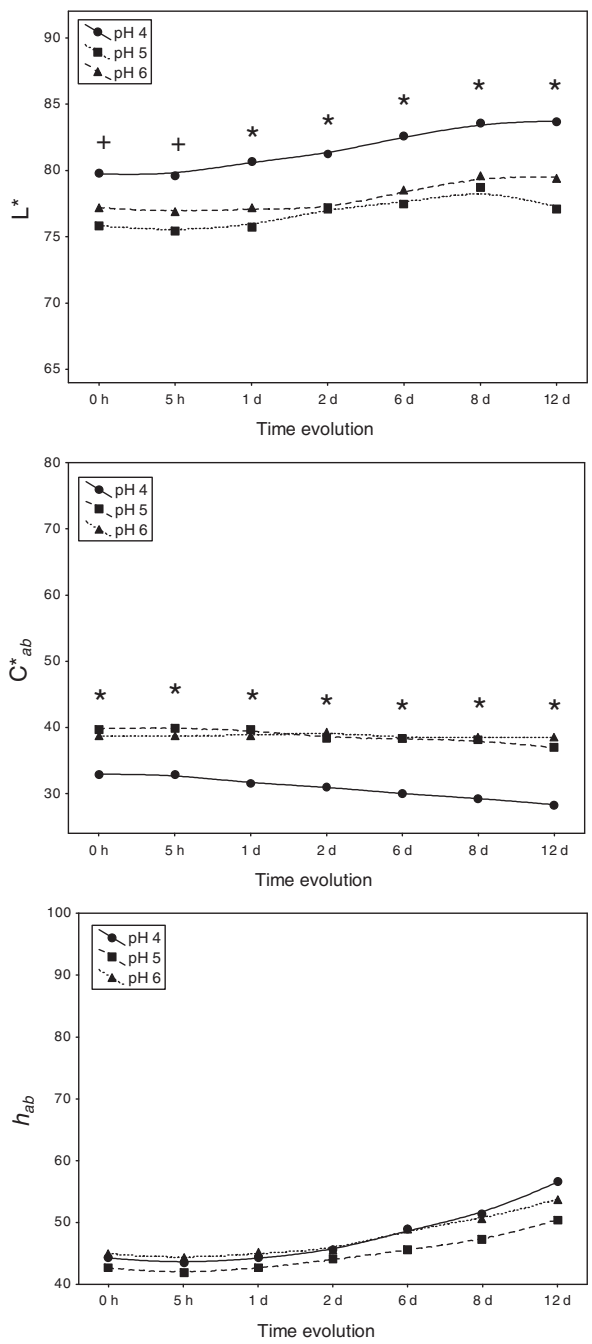

$20^{\circ} \mathrm{C}$
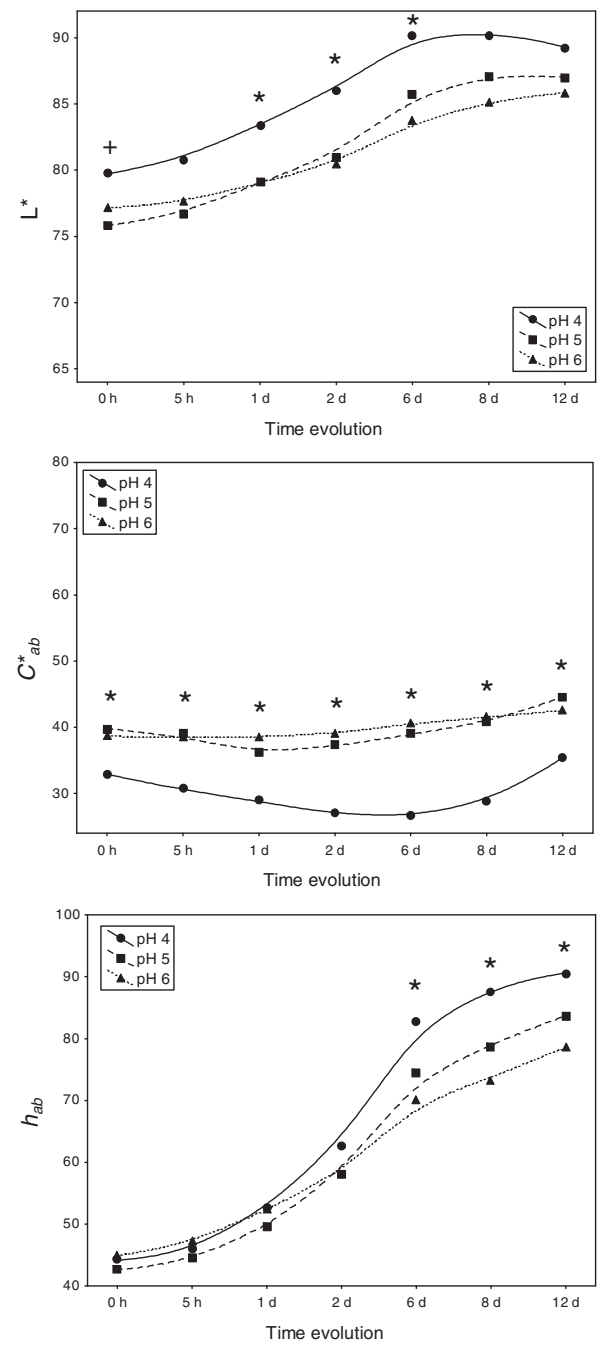

$80^{\circ} \mathrm{C}$
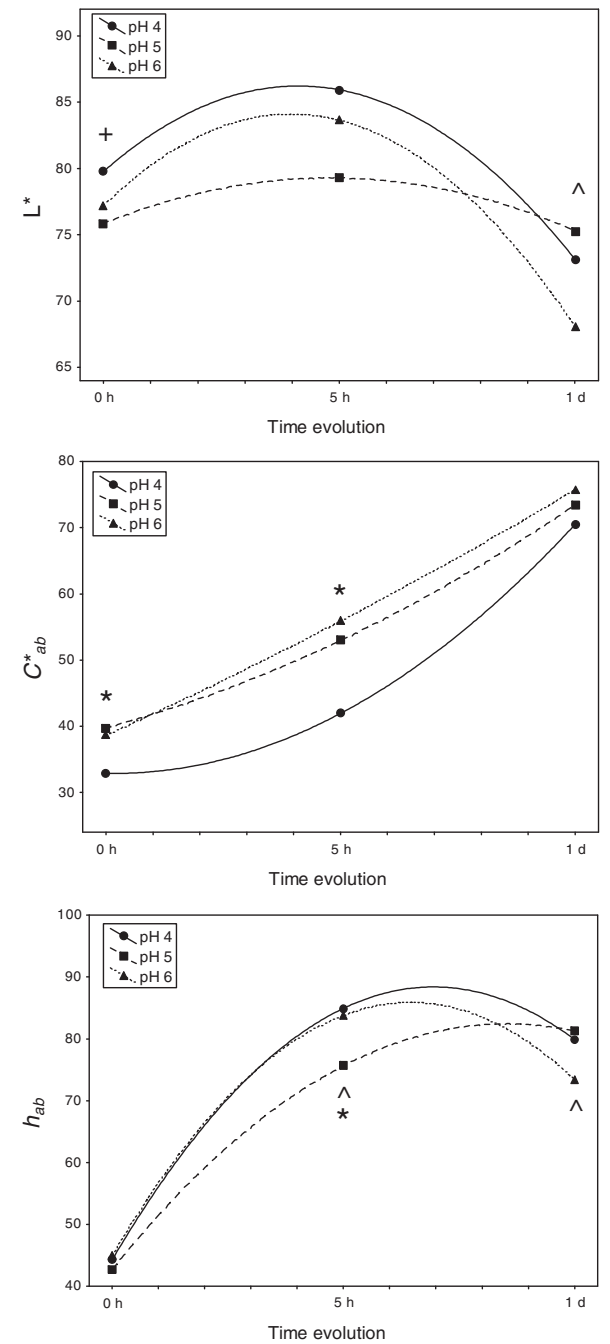

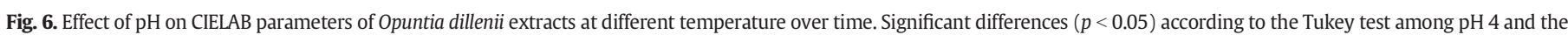
rest of $\mathrm{pHs}\left({ }^{*}\right)$, among $\mathrm{pH} 4$ and $5(+)$, and among $\mathrm{pH} 5$ and $6\left(^{\wedge}\right)$. 
reach a higher colorant intensity of the foodstuff. Similar results were obtained by Cejudo-Bastante et al. (2014) after developing stabilization assays on Ullucus tuberosus. Moreover, pH also exerted an important effect on lightness $\left(L^{*}\right)$, with the significantly $(p<0.05)$ highest values of the highly-acidic extracts at each time-point. Furthermore, it is important to highlight that the aforementioned commented change toward yellowish tonality after room temperature storage was much more accentuated as pH decrease, contrarily to that found (Hurtado, Morales, GonzálezMiret, Escudero-Gilete, \& Heredia, 2009) when a pH stability assay was carried out in anthocyanin-rich tamarillo (Solanum betaceum Cav.). When samples were heated $\left(80^{\circ} \mathrm{C}\right)$, scarce variations according to $\mathrm{pH}$ were manifested among them.

Regarding the $\left(a^{*} b^{*}\right)$-color diagram, the effect of $\mathrm{pH}$ was more pronounced in the behavior of $b^{*}$ (Fig. 7). Thus, at each time-point, highly-acidic extracts presented a significantly lower values of the component $b^{*}$ of the color. That fact means that $O$. dillenii extracts became less yellow when they were added to acid food products.

Overall, 0 . dillenii extracts could be more suitable for being added to low-acidic foods (meats, for example) because the hue and color stability increased with $\mathrm{pH}$. If it was needed to add extracts to more acidic food to promote red color, more quantity must be added to counteract the lower colorant intensity. However, the fact that highly-acidic O. dillenii extracts would be directed hopelessly towards yellowish dyes would be also exploited by colorant industry. That is to say that, the voluntary submission of 0 . dillenii extracts at 6 days of storage at room temperature or $5 \mathrm{~h}$ of heating would be used for complementing highly-acidic foods with yellow color (such as yogurts, fruit smoothies, ice creams, jams, to name a few).

\subsection{2. $\mathrm{pH}$ and differential colorimetry}

The pattern evolution of the color differences $\left(\Delta E^{*}{ }_{a b}\right)$ among pHs over time at each temperature was showed in Fig. 8. As it can be seen, $\mathrm{pH}$ exerted an important effect in color differences. As $\Delta E^{*}{ }_{a b}>3$, it could be asserted that color differences were appreciable among highly- (pH 4) and low-acidic extracts (pH 5 and 6), whatever the temperature applied. So, it could be confirmed that it was $\mathrm{pH} 4$ the acidity which established the limit from after color differences were visually appreciable. When compared among low-acidic extracts ( $\mathrm{pH} 5$ against $\mathrm{pH} 6$ ), $\Delta E_{a b}^{*}$ was maintained over time in values below 3 , indicating that they cannot be visually discriminated regardless of temperature (Fig. 8). Also visually discrimination upon heating was already found by Fernández-López et al. (2013) when the submitted temperature on several red pigment extracts was $50{ }^{\circ} \mathrm{C}$.

Thereby, at both $4{ }^{\circ} \mathrm{C}$ and $20^{\circ} \mathrm{C}$, color differences were mainly quantitative $\left(\Delta^{2} C\right.$ and $\Delta^{2} L$ ) and due to the different behavior of highly-acid extracts ( $\mathrm{pH} 4)$, although qualitative differences $\left(\Delta^{2} H\right)$ also contributed in the last steps of the storage at room temperature (6-12 days). At $80{ }^{\circ} \mathrm{C}$, there were hue and lightness $\left(\Delta^{2} H\right.$ and $\left.\Delta^{2} L\right)$ the main contributors to color differences, although an important qualitative participation of chroma took also on special significance (data not shown).

\subsection{3. $\mathrm{pH}$ and betalain content}

$\mathrm{pH}$ exerted an influent effect on the maximum absorption at the two wavelengths ( 484 and $535 \mathrm{~nm}$ ) for each temperature (Fig. 4). The timesequence of the spectra of 0 . dillenii extracts followed a chronological descendent order until the 8 days of storage. Subsequently, the behavior depended on temperature.

At the beginning of the treatment, although without significant differences $(p>0.05)$, the most abundant absorptions of both wavelengths was attributed to extracts adjusted to $\mathrm{pH} 5$ (in agreement with SanchezGonzalez et al. (2013)), followed by pH 6 and pH 4 (Fig. 4). That fact was directly related to the concentration of betaxanthins and betacyanins, respectively, which were significantly $(p<0.05)$ higher in low-acidic foodstuffs (Fig. 9). Over time, the diminution of the absorbance at 484 and $535 \mathrm{~nm}$ between $0 \mathrm{~h}$ and 12 days was mitigated as $\mathrm{pH}$ increased, similarly to that observed by Castellar et al. (2003) in several species of Opuntia sp. and by Cejudo-Bastante et al. (2014) in other raw materials. That fact could be extrapolated to the betaxanthins' and betacyanins' content, respectively (Fig. 9), whose percentage of diminution over time in highly- $(\mathrm{pH} 4)$ and low-acidic foods ( $\mathrm{pH} 6)$ ranged
$4{ }^{\circ} \mathrm{C}$

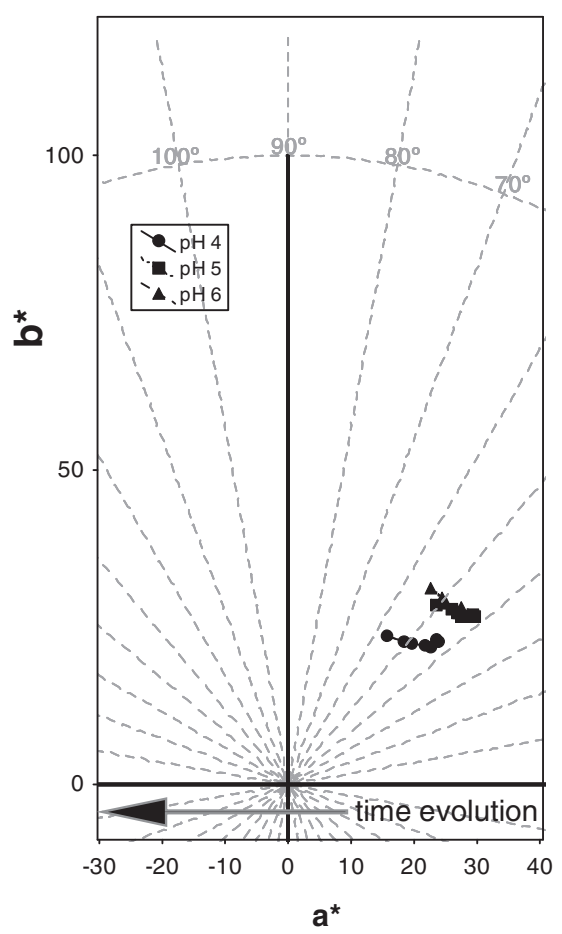

$20^{\circ} \mathrm{C}$

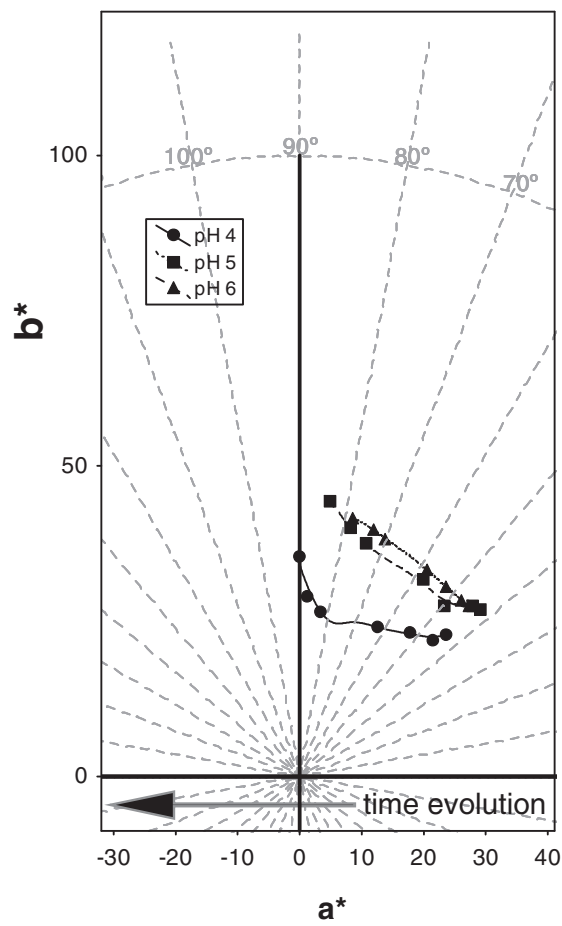

$80^{\circ} \mathrm{C}$

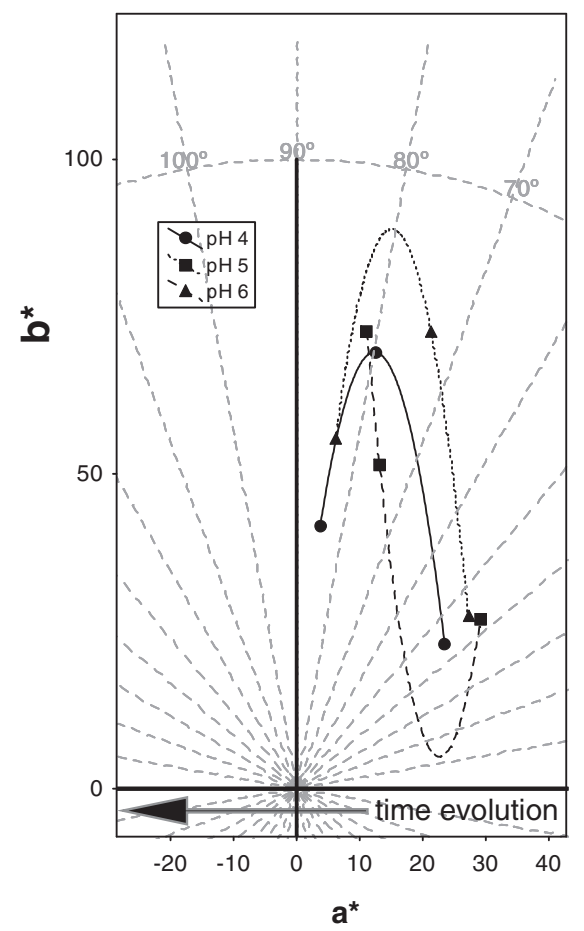

Fig. 7. Effect of pH on CIELAB color space ( $\left.a^{*} b^{*}\right)$-plane of Opuntia dillenii extracts at different temperature over time. 

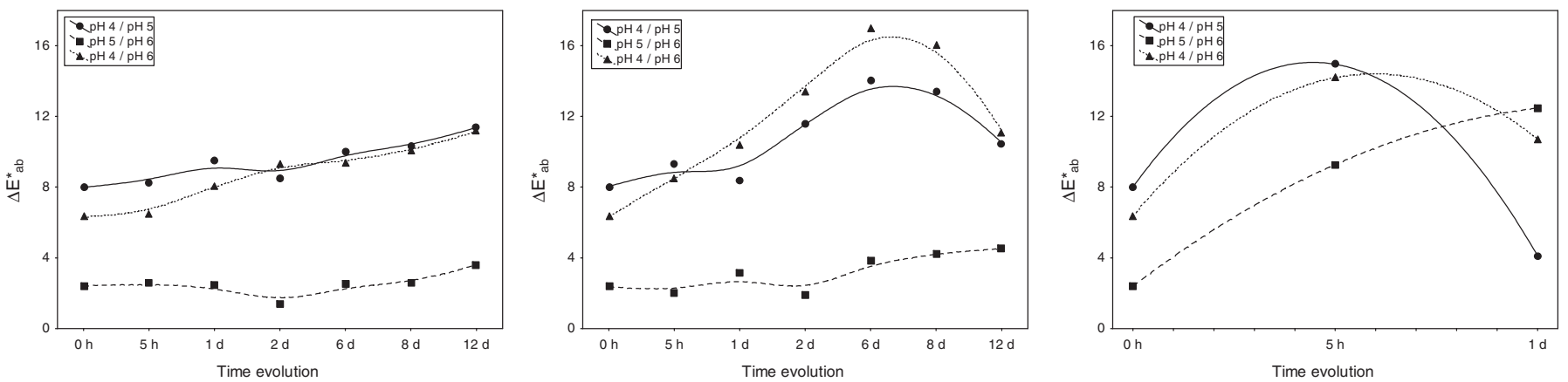

Fig. 8. Color variation $\left(\Delta \mathrm{E}_{\mathrm{ab}}^{*}\right)$ of Opuntia dillenii extracts among different $\mathrm{pHs}$ at each studied temperature.

between $20-40 \%$ and $4-25 \%$ in betaxanthins, and among $25-65 \%$ and $15-50 \%$ in betacyanins. Therefore, and regardless of temperature, the betalain stability of 0 . dillenii extracts depended on the $\mathrm{pH}$, because betalains were most stable in low-acidic foods with significantly $(p<0.05)$ higher values at each time-sequence (Fig. 9). That results were contrary to that affirmed Cejudo-Bastante et al. (2014) in U. tuberosus.

Similarly, pH also showed a clear effect on the demeanor of heattreated 0 . dillenii extracts $\left(80{ }^{\circ} \mathrm{C}\right)$; the content of betacyanins greatly decreased in the samples adjusted to $\mathrm{pH} 4$ and 6. However, samples with medium-acidity did not experiment remarkable changes on the content of both chemical families after $5 \mathrm{~h}$ of treatment, leading them in the most significantly abundant betalain content $(p<0.05)$.

\section{Conclusions}

It has been demonstrated that 0 . dillenii is a raw material suitable for being used as natural colorant in a wide range of $\mathrm{pH}$ products and under different processing and storage conditions. Hence, at least during two days of treatment, the red nuance of the foodstuff to which 0 . dillenii was added would be independent of their acidity. In the case of a long lasting storage, it would be the temperature which dictates the food tonality containing the $O$. dillenii colorant. Thus, $O$. dillenii extracts added to highly-acidic foods (vegetables- or fruit-based dishes) and kept at room temperature provided a significantly more yellowish dye and more lightness than the low-acidic foodstuffs. If samples were conserved under cold refrigeration, food products of diverse acidities would not have differences on the hue but it could be necessary to add higher quantity of extract to highly-acidic food to counteract their lower colorant intensity and betalain content. Even when food was cooked $\left(80^{\circ} \mathrm{C}\right)$ the colorant intensity provided by the highly-acidic extract would be lower. Finally, this research could be interesting because it has deepened not only in the occurrence of new natural sources as colorants, but also in how the extract might change the color and betalain content according to the nature of the product where it is added and to the different ways of processing. In addition, this study could be directly applicable not only to food industry, but also to other kind of trades in which the color, is the target market (such as
4 ㄷ
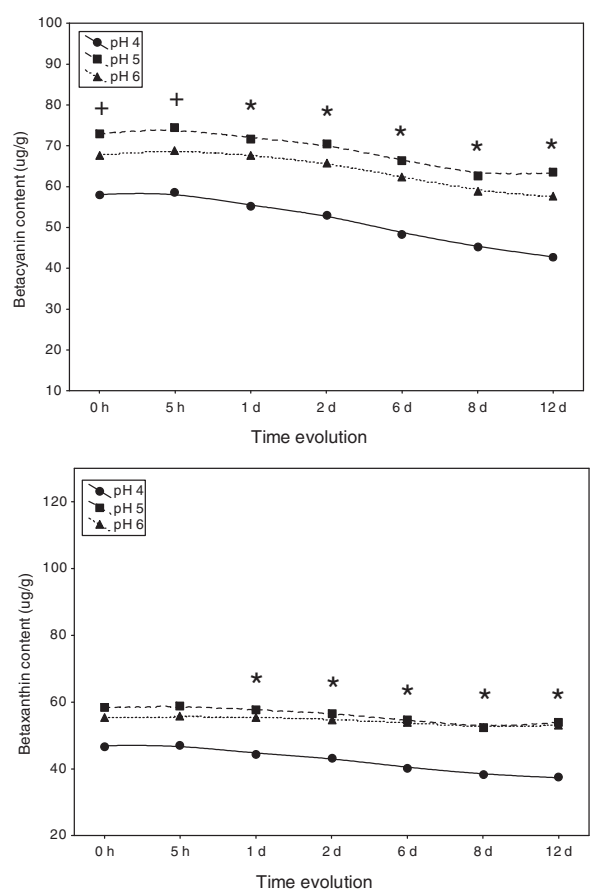

$20 \stackrel{\circ}{ }$
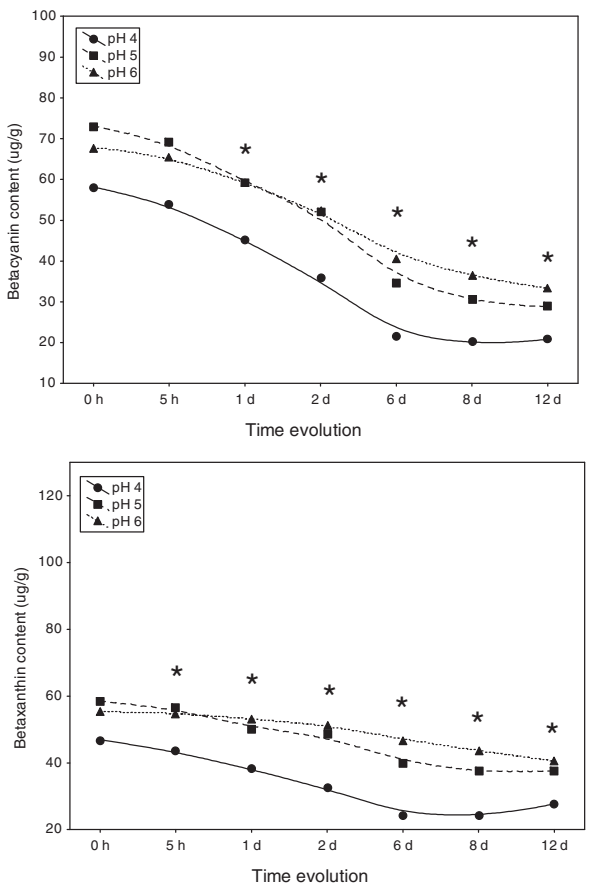

$80 \stackrel{\circ}{ } \mathrm{C}$
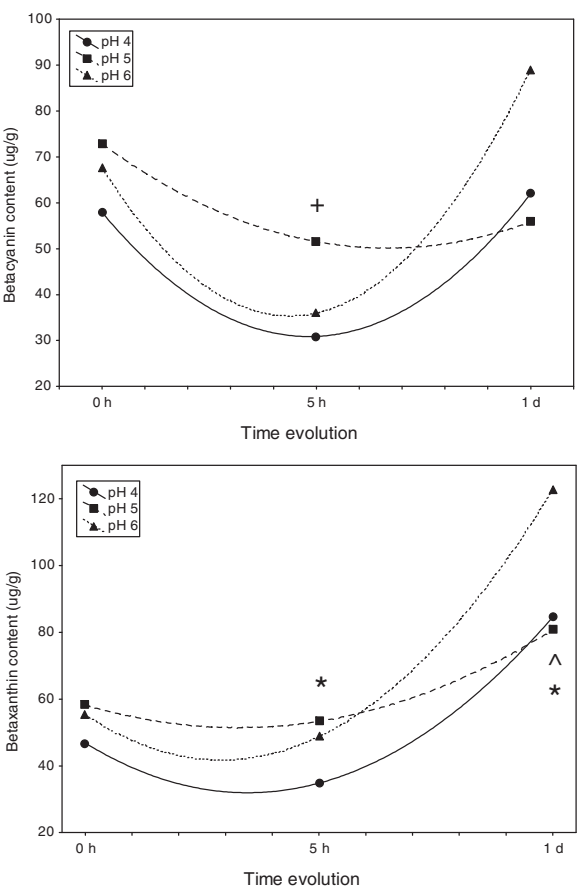

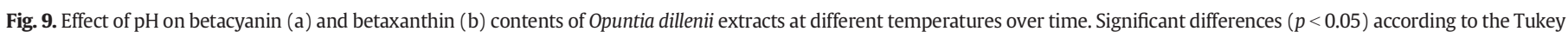
test among pH 4 and the rest of pHs $\left({ }^{*}\right)$, among pH 4 and $5(+)$, and among pH 5 and $6\left(^{\wedge}\right)$. 
cosmetics, pharmaceutics, drugs and paints, among others). Although further researches are needed in relation to natural colorants, such as a chemical individual betalain characterization of scarcely studied sources, this study could be a great step forward to displace synthetic colorants.

\section{Funding}

Financial support by Consejería de Economía, Innovación y Ciencia, Junta de Andalucía, Spain (Project P11-AGR-7843) is gratefully acknowledged.

\section{Acknowledgments}

We thank technical staff of Biology Service (SGI, Universidad de Sevilla) and Universidad de Nariño, San Juan de Pasto, Colombia.

\section{References}

Azeredo, H. M. C. (2009). Betalains: Properties, sources, applications, and stability - A review. International Journal of Food Science and Technology, 44, 2365-2376.

Butera, D., Tesoriere, L., Di Gaudio, F., Bongiorno, A., Allegra, M., Pintaudi, A. M., et al. (2002). Antioxidant activities of Sicilian prickly pear (Opuntia ficus indica) fruit extracts and reducing properties of its betalains: Betanin and indicaxanthin. Journal of Agricultural and Food Chemistry, 50, 6895-6901.

Cai, Y., Sun, M., \& Corke, H. (1998). Colorant properties and stability of Amaranthus betacyanin pigments. Journal of Agricultural and Food Chemistry, 46, 4491-4495.

Castellanos-Santiago, E. \& Yahia, E. M. (2008). Identification and quantification of betalains from the fruits of 10 Mexican prickly pear cultivars by high-performance liquid chromatography and electrospray ionization mass spectrometry. Journal of Agricultural and Food Chemistry, 56, 5758-5764.

Castellar, R., Obón, J. M., Alacid, M., \& Fernández-López, J. A. (2003). Color properties and stability of betacyanins from Opuntia fruits. Journal of Agricultural and Food Chemistry, $51,2772-2776$.

Castellar, M. R, Obón, J. M \& Fernández-López J. A (2006). The isolation and properties of a concentrated red-purple betacyanin food colourant from Opuntia stricta fruits. Journal of the Science of Food and Agriculture, 86, 122-128.

Cejudo-Bastante, M. J., Hurtado, N., Mosquera, N., \& Heredia, F. J. (2014). Potential use of new Colombian sources of betalains. Color stability of ulluco (Ullucus tuberosus) extracts under different $\mathrm{pH}$ and thermal conditions. Food Research International, 64, 465-471.

Chang, S. F., Hsieh, C. L., \& Yen, G. C. (2008). The protective effect of Opuntia dillenii Haw fruit against low-density lipoprotein peroxidation and its active compounds. Food Chemistry, 106, 569-575.

CIE (2004). Technical Report Colorimetry. Vienna, Austria: Commission Internationale de l'Eclairage Central Bureau.

El Hosry, L., Auezova, L., Sakr, A., \& Hajj-Moussa, E. (2009). Browning susceptibility of white wine and antioxidant effect of glutathione. International Journal of Food Science and Technology, 44, 2459-2463.

Fernández-López, J. A., Angosto, J. M., Giménez, P. J., \& León, G. (2013). Thermal stability of selected natural red extracts used as food colorants. Plant Foods for Human Nutrition, $68,11-17$.
Fernández-Zurbano, P. Ferreira, V Peña, C Escudero, A Serrano, F \& Cacho, J. (1995) Prediction of oxidative browning in white wines as a function of their chemical composition. Journal of Agricultural and Food Chemistry, 43, 2813-2817.

Gordillo, B., Rodríguez-Pulido, F. J., Mateus, N., Escudero-Gilete, M. L., González-Miret, M. L., Heredia, F. J., et al. (2012). Application of LC-MS and tristimulus colorimetry to assess the ageing aptitude of Syrah wine in the Condado de Huelva D.O. (Spain), a typical warm climate region. Analytica Chimica Acta, 732, 162-171.

Herbach, K. M., Stintzing, F. C., \& Carle, R. (2004). Impact of thermal treatment on color and pigment pattern of red beet (Beta vulgaris L.) preparations. Journal of Food Science, 69, C491-C498.

Herbach, K. M., Stintzing, F. C., \& Carle, R. (2006). Betalain stability and degradation Structural and chromatic aspects. Journal of Food Science, 71, R41-R50.

Heredia, F. J., Álvarez, C., González-Miret, M. L., \& Ramírez, A. (2004). CromaLab, Análisis de color. Registro General de la Propiedad Intelectual.

Hurtado, N. H., Morales, A. L., González-Miret, M. L., Escudero-Gilete, M. L., \& Heredia, F. J. (2009). Colour, pH stability and antioxidant activity of anthocyanin rutinosides isolated from tamarillo fruit (Solanum betaceum Cav.). Food Chemistry, 117, 88-93.

Kugler, F., Stintzing, F. C., \& Carle, R. (2007). Characterisation of betalain patterns of differently coloured inflorescences from Gomphrena globosa L. and Bougainvillea sp. by HPLC-DAD-ESI-MSn. Analytical and Bioanalytical Chemistry, 387, 637-648.

Liu, W., Fu, Y. J., Zu, Y. G., Tong, M. H., Wu, N., Liu, X. L., et al. (2009). Supercritical carbon dioxide extraction of seed oil from Opuntia dillenii Haw. and its antioxidant activity. Food Chemistry, 114, 334-339.

Martínez, J. A., Melgosa, M., Pérez, M. M., Hita, E., \& Negueruela, A. I. (2001). Note. Visual and instrumental color evaluation in red wines. Food Science and Technology International, 7, 439-444.

Medina, E. M. D., Rodríguez, E. M. R., \& Romero, C. D. (2007). Chemical characterization of Opuntia dillenii and Opuntia ficus indica fruits. Food Chemistry, 103, 38-45.

Nemzer, B., Pietrzkowski, Z Spórna, A., Stalica, P., Thresher, W., Michałowski, T, et al. (2011). Betalainic and nutritional profiles of pigment-enriched red beet root (Beta vulgaris L.) dried extracts. Food Chemistry, 127, 42-53.

Pavokovi, D., \& Krsnik-Rasol, M. (2011). Complex biochemistry and biotechnological production of betalains. Food Technology and Biotechnology, 49, 145-155.

Sanchez-Gonzalez, N., Jaime-Fonseca, M. R., San Martin-Martinez, E., \& Zepeda, L. G. (2013). Extraction, stability, and separation of betalains from Opuntia joconostle cv. using response surface methodology. Journal of Agricultural and Food Chemistry, 61, 11995-12004.

Statistica (2007). StatSoft Inc. STATISTICA (Data Analysis Software System). (Tulsa, OK, USA, Computer software).

Stintzing, F. C., Schieber, A., \& Carle, R. (2002a). Betacyanins in fruits from red-purple pitaya, Hylocereus polyrhizus (Weber) Britton \& Rose. Food Chemistry, 77, 101-106.

Stintzing, F. C., Schieber, A., \& Carle, R. (2002b). Identification of betalains from yellow beet (Beta vulgaris L.) and cactus pear [Opuntia ficus-indica (L.) Mill.] by highperformance liquid chromatography-electrospray ionization mass spectrometry. Journal of Agricultural and Food Chemistry, 50, 2302-2307.

Svenson, J., Smallfield, B. M., Joyce, N. I., Sansom, C. E., \& Perry, N. B. (2008). Betalains in red and yellow varieties of the Andean tuber crop ulluco (Ullucus tuberosus). Journal of Agricultural and Food Chemistry, 56, 7730-7737.

Touil, A., Chemkhi, S., \& Zagrouba, F. (2010). Physico-chemical characterisation of Opuntia dillenii fruit. International Journal of Food Engineering, 6 (article 5).

Waterman, P. G. (2007). The current status of chemical systematics. Phytochemistry, 68, 2896-2903.

Yang, Q., Chen, H., Zhou, X., \& Zhang, J. (2013). Optimum extraction of polysaccharides from Opuntia dillenii and evaluation of its antioxidant activities. Carbohydrate Polymers, 97, 736-742. 